\title{
U.S. International Transactions in 1998
}

Kathryn A. Morisse, of the Board's Division of International Finance, prepared this article. Nancy E. Baer provided research assistance.

U.S. external deficits widened substantially in 1998 because of the disparity between the rapid pace of U.S. economic growth and sluggish growth abroad and also because of the decline in the price competitiveness of U.S. goods associated with the appreciation of the dollar. The nominal current account deficit reached $\$ 233$ billion in 1998, compared with $\$ 155$ billion in 1997; the 1998 deficit was 2.7 percent of U.S. gross domestic product, the largest share since 1987.

Most of the widening in the deficit was in trade in goods and services (table 1). The financial crises in Asia that emerged in the second half of 1997 caused U.S. exports to drop sharply in the first half of 1998. Robust U.S. domestic demand was largely responsible for the brisk rise in imports during the year. Net investment income was negative in 1998 for the second consecutive year; these were the first negatives recorded since 1914. Cumulative deficits in the current account, and the associated capital inflows that have persisted since 1982, have resulted in payments of income on foreign investment in the United States growing more rapidly than receipts of income on U.S. investments abroad.

The large U.S. current account deficit last year was financed entirely by net capital inflows from private sources. Official capital flows, which registered mod- est inflows in 1997, turned to moderate outflows on balance last year as the financial turmoil in the third quarter caused many countries to draw down their official reserves.

\section{MAJOR ECONOMIC INFLUENCES ON U.S. INTERNATIONAL TRANSACTIONS}

Developments in U.S. current and capital account transactions in 1998 were shaped by a wide variety of factors: financial crises in emerging markets, the resulting sluggishness of economic activity in emerging markets and elsewhere, the effects of persistent problems in Japan, the robust expansion of the U.S. economy, and the appreciation of the dollar.

\section{Financial Crises in Emerging Markets}

Developments in international financial markets continued to be dominated by the unfolding crises in emerging markets that had begun in Thailand in 1997. Turbulence in Asian financial markets spread to other emerging markets around the globe-from Korea, Indonesia, and other countries in Asia during 1997 and the first part of 1998, then to Russia last summer, and shortly thereafter to Latin America, particularly Brazil.

At the beginning of the year, various Asian currencies were under pressure. The Indonesian rupiah

1. U.S. international transactions in 1994-98

Billions of dollars except as noted

\begin{tabular}{|c|c|c|c|c|c|c|}
\hline Item & 1994 & 1995 & 1996 & 1997 & 1998 & $\begin{array}{l}\text { Change, } \\
1997 \text { to } 1998\end{array}$ \\
\hline Trade in goods and services, net & -101 & -100 & -109 & -110 & -169 & -59 \\
\hline $\begin{array}{l}\text { Investment income, net } \ldots \ldots \ldots \\
\text { Unilateral transfers, net } \ldots \ldots \ldots\end{array}$ & $\begin{array}{r}17 \\
-39\end{array}$ & $\begin{array}{r}19 \\
-35\end{array}$ & $\begin{array}{r}14 \\
-41\end{array}$ & $\begin{array}{r}-5 \\
-40\end{array}$ & $\begin{array}{l}-22 \\
-42\end{array}$ & $\begin{array}{r}-17 \\
-2\end{array}$ \\
\hline Current account balance . & -124 & -115 & -135 & -155 & -233 & -78 \\
\hline $\begin{array}{l}\text { Official capital, net } \ldots . \\
\text { Private capital, net } \ldots . .\end{array}$ & $\begin{array}{l}45 \\
89\end{array}$ & $\begin{array}{l}99 \\
39\end{array}$ & $\begin{array}{r}133 \\
61\end{array}$ & $\begin{array}{r}15 \\
240\end{array}$ & $\begin{array}{l}-30 \\
267\end{array}$ & $\begin{array}{r}-45 \\
27\end{array}$ \\
\hline Statistical discrepancy & -10 & -23 & -60 & -100 & -4 & 96 \\
\hline $\begin{array}{l}\text { MEMO } \\
\text { Current account as percentage of GDP }\end{array}$ & -1.8 & -1.6 & -1.8 & -1.9 & -2.7 & \\
\hline
\end{tabular}

Note. In this and the tables that follow, components may not sum to totals because of rounding.

. . Not applicable. 
1. U.S. dollar exchange rates for selected currencies in Asia, 1997-March 1999

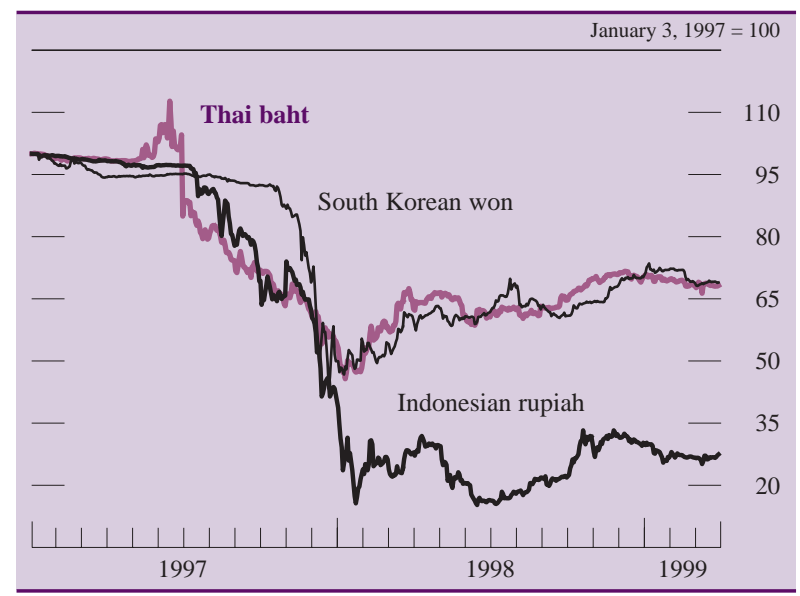

NotE. U.S. dollars per unit of foreign currency. The data are daily.

dropped sharply in response to several factors, including rising political unrest that led ultimately to the resignation of President Suharto. Although the rupiah recovered substantially in the second half of the year, it depreciated 35 percent against the dollar between December 1997 and December 1998 (chart 1). In contrast, the Thai baht and Korean won, which had declined sharply in 1997, gained more than 20 percent against the dollar over the course of 1998; policy reforms and stable political environments helped boost these currencies. Between these extremes, the currencies of the Philippines, Malaysia, Singapore, and Taiwan fluctuated in a narrower range and ended the year little changed against the dollar. The Hong Kong dollar came under pressure at times during the year, but its peg to the U.S. dollar remained intact at the cost of interest rates that were at times quite high. Short-term interest rates in Asian economies other than Indonesia declined in 1998; as some stability returned to Indonesian markets near the end of the year, short-term rates in that nation began to retreat from their highs.

As the financial storm moved to Russia (chart 2), the Russian central bank was able to defend the ruble's peg only temporarily. Faced with deep structural and political problems leading to a severe erosion in investor confidence, Russia on August 17 announced a devaluation of the ruble and a moratorium on servicing official short-term debt. Within a few days the new rate was abandoned, and the ruble fell more than 70 percent against dollar by the end of the year. The government imposed conditions on most of its foreign and domestic debt that implied substantial losses for creditors, and many Russian financial institutions became insolvent. The events
2. U.S. dollar exchange rate for the Russian ruble, 1997-February 1999

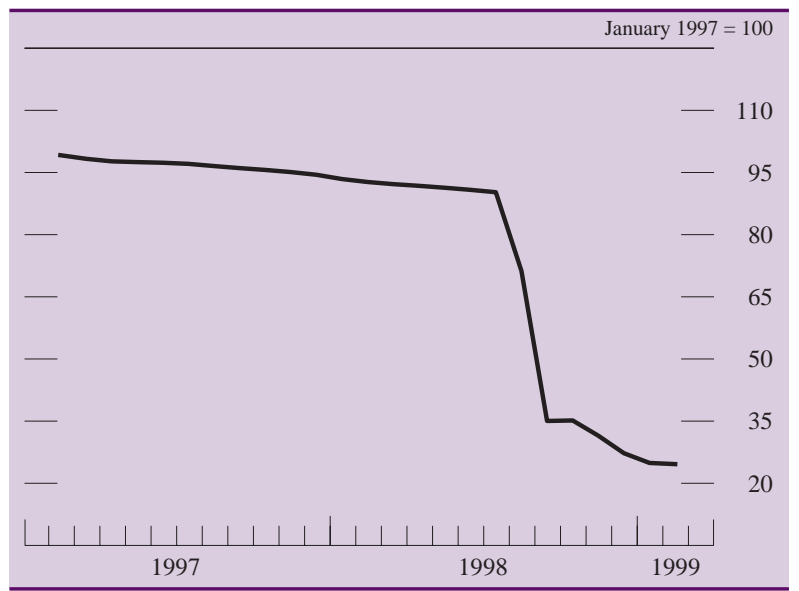

Note. U.S. dollars per ruble. The data are monthly.

in Russia precipitated an increase in global financial market turbulence.

Latin American financial markets were only moderately disrupted by the Asian and Russian problems during the first half of 1998. Their reaction to the Russian default, however, was swift and strong, and the prices of Latin American assets fell precipitously. Brazil experienced a sharp acceleration of capital outflows. The Mexican peso, which was also weakened by the effects of falling oil prices, depreciated 18 percent against the dollar over the year (chart 3). Argentina's currency board arrangement came under pressure but withstood it successfully.

Shortly after details of an IMF-led financial assistance package for Brazil were announced in November 1998, Brazil's Congress rejected a part of the

3. U.S. dollar exchange rates for selected currencies in Latin America, 1997-March 1999

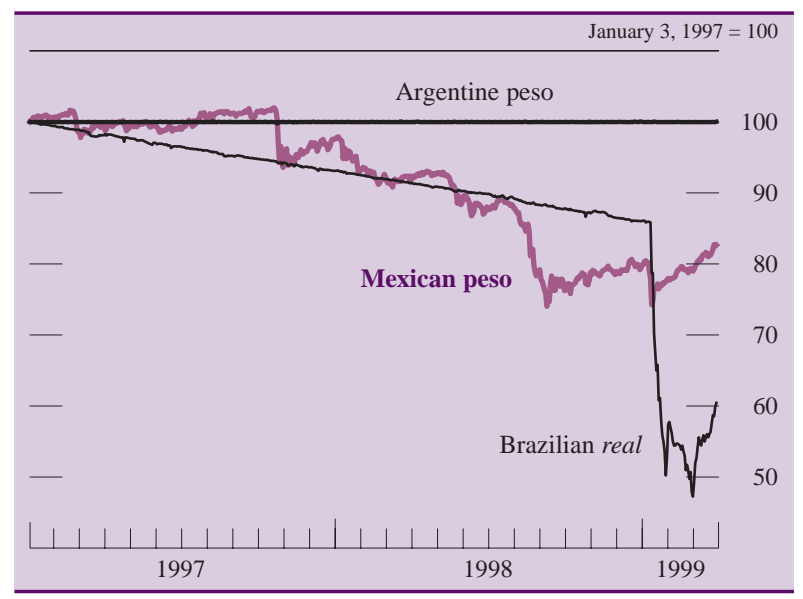

Note. U.S. dollars per unit of foreign currency. The data are daily. 
government's fiscal austerity plan, sparking additional financial turmoil. As the year ended, the continuing pressure from capital seeking to leave Brazil left much uncertainty about the long-run viability of the crawling exchange rate peg. Brazil's central bank defended the real's crawling peg until mid-January 1999 but in the process is estimated to have used more than half of the $\$ 75$ billion in foreign exchange reserves it had amassed as of last April. On January 13 the real was devalued 8 percent. Two days later it was allowed to float, and by the end of March the real was 30 percent below its pre-devaluation level.

\section{Economic Activity Abroad}

The fallout from the financial crises triggered declines in output in various countries, with the largest declines coming in emerging markets (table 2). The Asian crises also contributed to a deepening recession in Japan last year, and as the year progressed, growth in several other major foreign industrial economies slowed as well.

\section{Developments in Emerging Markets}

In the countries most heavily affected in AsiaThailand, Korea, Malaysia and Indonesia-output dropped at double-digit annual rates in the first half of the year as credit disruptions, some tightening of macroeconomic policies, and widespread failures in the financial and corporate sectors created a high degree of economic uncertainty. Output in Hong Kong also dropped in early 1998, as interest rates rose sharply amid pressure on its currency peg. The Asian crisis had a relatively modest impact on China. Chinese growth remained fairly strong throughout 1998, despite a dramatic slowdown in exports. Later in the year, financial conditions in most of the Asian crisis countries stabilized somewhat, and output in some countries showed signs of recovery.

On average, overall inflation in the Asian developing economies rose only moderately in 1998, as the inflationary impacts of currency depreciations in the region were largely offset by the deflationary influence of very weak domestic activity. The current account balances of the Asian crisis countries swung into substantial surplus in 1998: Imports dropped sharply in response both to the fall-off in domestic demand and to the improvement in the countries' competitive positions associated with the substantial depreciations of their currencies in late 1997 and early 1998.

In Russia, the fall in economic activity accelerated after the August debt moratorium and ruble devaluation, and by the end of the year output was about 10 percent below levels of a year earlier. The collapse of the ruble and the monetary expansion to finance Russia's budget deficit led to a surge in inflation to triple-digit rates during the latter part of the year.

2. Change in real GDP in the United States and abroad, 1996-98

Percent, annual rate

\begin{tabular}{|c|c|c|c|c|c|c|}
\hline \multirow{2}{*}{ Country } & \multirow{2}{*}{1996} & \multirow{2}{*}{1997} & \multirow{2}{*}{1998} & \multicolumn{3}{|c|}{ Half years } \\
\hline & & & & 1997:H2 & 1998:H1 & 1998:H2 \\
\hline United States & 3.9 & 3.8 & 4.2 & 3.6 & 3.7 & 4.8 \\
\hline Total foreign ${ }^{1}$ & 4.1 & 4.1 & .5 & 3.2 & -.1 & 1.1 \\
\hline Asian emerging markets ${ }^{2}$ & 7.0 & 5.1 & -2.8 & 2.7 & -6.9 & 1.4 \\
\hline Thailand........... & 3.8 & -3.8 & -8.4 & -6.7 & -15.0 & -1.4 \\
\hline Korea ... & 7.0 & 3.7 & -5.3 & .2 & -13.3 & 3.4 \\
\hline Malaysia & 10.4 & 6.8 & -10.1 & 6.5 & -18.6 & -.6 \\
\hline Indonesia .. & 10.2 & 2.3 & -19.6 & 2.9 & -25.3 & -13.4 \\
\hline Hong Kong & 5.7 & 2.8 & -5.7 & -1.7 & -8.4 & -2.9 \\
\hline China ..... & 9.4 & 7.9 & 9.2 & 6.8 & 6.9 & 11.6 \\
\hline Latin America ${ }^{3}$ & 6.4 & 6.3 & .9 & 4.4 & 3.1 & -1.2 \\
\hline Mexico ....... & 7.5 & 7.2 & 2.9 & 4.8 & 3.8 & 1.9 \\
\hline Brazil .... & 5.0 & 2.0 & -1.9 & .2 & 2.7 & -6.2 \\
\hline Argentina & 9.4 & 8.5 & -0.5 & 9.5 & 5.1 & -5.8 \\
\hline Venezuela & .9 & 5.5 & -8.2 & 1.2 & 2.2 & -17.6 \\
\hline Japan ... & 5.1 & -.8 & -3.0 & .2 & -3.8 & -2.2 \\
\hline Canada ........ & 1.7 & 4.4 & 2.8 & 3.6 & 2.4 & 3.1 \\
\hline Western Europe ......... & 2.4 & 3.8 & 2.4 & 3.5 & 2.8 & 1.9 \\
\hline
\end{tabular}

NotE. Aggregate measures are weighted by moving bilateral shares in U.S. exports of nonagricultural merchandise. Annual data are four-quarter changes. Half-yearly data are calculated as Q4/Q2 or Q2/Q4 changes at an annual rate. The data are partly estimated.

1. Selected regions and countries are shown below.
2. Weighted average of China, Hong Kong, Indonesia, Korea, Malaysia, Philippines, Singapore, Taiwan, and Thailand.

3. Weighted average of Mexico, Argentina, Brazil, Chile, Colombia, and Venezuela.

SOURCE. Various national sources. 
In Latin America, the pace of activity slowed only moderately in the first half of 1998, when the spillover from the Asian financial turbulence was limited (table 2). In contrast, the Russian financial crisis in August had a strong effect on real activity in Latin America. The effect was particularly strong in Brazil, where interest rates moved sharply higher in response to exchange rate pressures and domestic demand weakened significantly. Output in Argentina declined in the second half of 1998, and activity in Mexico and Venezuela was depressed by lower oil export revenues as well as by turbulence in international financial markets. Inflation rates in Latin American countries changed little in 1998.

\section{Developments in Japan}

Japanese economic activity contracted in 1998 as Japan remained in its most protracted recession of the postwar era (table 2). The plunge in business and residential investment and stagnating private consumption more than offset positive contributions from government spending and net exports. Core consumer prices in Japan were down slightly in 1998 on a fourth-quarter to fourth-quarter basis, and wholesale prices plunged $3 \frac{1}{2} 2$ percent. In an effort to revive the economy, the Japanese government in April announced a large fiscal stimulus package that included temporary tax cuts and substantial increases in public works expenditures. A second sizable set of fiscal stimulus measures was announced in late 1998 and is slated for implementation during 1999. In September the Bank of Japan cut its target for the overnight call-money rate from 0.5 percent to a low of 0.25 percent in an effort to offset deflationary pressures and to support economic activity. The rate was cut again, to near zero, by March 1999 .

\section{Developments in Other Foreign Industrial Countries}

In the euro area, domestic demand strengthened moderately on balance over the year; employment rose and euro-area interest rates declined as the date for monetary union approached. Net exports weakened, however, in part because of the turmoil in emerging markets, and as a result, total output in the euro area slowed.

Output in the United Kingdom decelerated sharply as the effects of earlier monetary tightening registered on domestic demand and as exports slowed in response to the strength in sterling. Growth in Canada also fell back from its robust pace in 1997 as domestic demand responded to interest rates hikes aimed at blunting downward pressure on the Cana- dian dollar. Exports slowed despite support from strong U.S. demand and a weaker Canadian dollar because demand for Canada's commodity exports was diminished by the Asian crisis, but imports decelerated even more sharply, and thus net exports made a positive contribution to overall Canadian growth.

Consumer price inflation continued to slow in the euro area-twelve-month inflation fell to below 1 percent. In the United Kingdom, inflation slowed to near the government's target rate of $2 \frac{1}{2}$ percent. Canadian inflation remained low, just above 1 percent, despite significant currency depreciation.

The beginning of 1999 brought the birth of the euro, which marked the start of Stage Three of European Economic and Monetary Union (EMU). On December 31, 1998, the conversion rates between the euro and the eleven legacy currencies were determined. Based on these rates, the value of the euro at the moment of its inception was $\$ 1.16675$. After initially holding firm, the euro depreciated against the dollar through much of the first quarter as economic prospects in several key European countries appeared to soften.

\section{U.S. Economic Growth}

The U.S. economy grew at a vigorous pace in 1998 (table 2) and appears to have continued to be robust into the first quarter of 1999. Exceptional strength in the real expenditures of households and businesses reflected strong real income growth, large gains in the value of household wealth, ready access to finance during most of 1998, and widespread optimism regarding the future of the economy. Inflation remained subdued in 1998, and the increase in the general price level was smaller than in the previous year. The slowing of price increases was in large part a reflection of sluggish conditions in the world economy, which brought declines in prices of a wide range of imported goods, including oil and other primary commodities. In the domestic economy, nominal hourly compensation of workers picked up only slightly despite the tightness of the labor market, and much of the compensation increase was offset by gains in labor productivity. As a result, unit labor costs, the most important item in total business costs, rose only moderately.

\section{Exchange Value of the Dollar}

The dollar's value, measured on a trade-weighted basis, rose almost 7 percent during the first eight months of 1998 and then fell, reaching a level by 
December less than 2 percent above its year-earlier level (chart 4). ${ }^{1}$ The dollar's moves against the yen were particularly large, rising more than 10 percent in the first half of the year only to fall sharply in the second half, ending the year down about 10 percent from its year-earlier level. The dollar moved less against other major currencies, ending the year down 6 percent against the mark and up 8 percent against the Canadian dollar.

Before the Russian default, the dollar was supported by the robust pace of U.S. economic activity, which at times generated expectations that monetary policy would be tightened, and was in contrast to signs of weakening economic activity abroad, especially in Japan. Occasionally, however, the positive influence of the strong economy was countered by worries about the growing U.S. external deficits. The dollar fell sharply from August to October under pressure from the aftermath of the Russian financial meltdown, concerns that increased difficulties in Latin America might affect the U.S. economy disproportionately, and expectations of lower U.S. interest rates. The broad index of the dollar's exchange value eased a bit further during the fourth quarter of 1998.

1. The broad index of the dollar's foreign exchange value includes the currencies of important U.S. trading partners. Currencies of all foreign countries or regions that had a share of U.S. non-oil imports or nonagricultural exports of at least $1 / 2$ percent in 1997 are included in the index. The broad index included thirty-five currencies until the beginning of Stage Three of European Economic and Monetary Union, on January 1, 1999, when the euro replaced the ten euro-area currencies. The broad index now has twenty-six currencies. A more complete description of the index may be found in Michael P. Leahy, "New Summary Measures of the Foreign Exchange Value of the Dollar," Federal Reserve Bulletin, vol. 84 (October 1998), pp. 811-18.

4. Broad index of the U.S. dollar's foreign exchange value, 1990-March 1999

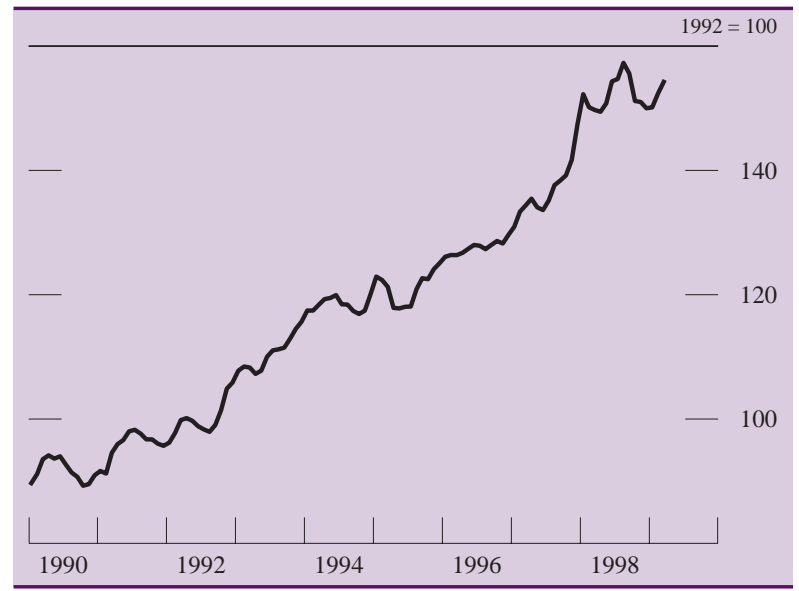

Note. See text note 1 for a description of the broad index. The data are monthly.
Between December and March 1999, the dollar gained nearly 3 percent in terms of the broad index.

\section{PRICES OF INTERNATIONALLY TRADED GOODS}

The combination of all these events abroad had a depressing effect on prices of internationally traded goods in 1998, particularly oil and other industrial materials and supplies.

\section{Primary Commodities}

Oil prices dropped significantly during 1998 to levels not seen since the price collapse of 1986 (chart 5). The average spot price for West Texas intermediate, the U.S. benchmark crude, fell from $\$ 19.91$ per barrel in the fourth quarter of 1997 to $\$ 12.87$ per barrel in the fourth quarter of 1998, a 35 percent decline. The price of imported oil dropped 36 percent over the same period. Overall, the fall in the price of petroleum-based energy products is estimated to have held down U.S. CPI inflation in 1998 by $1 / 2$ percentage point.

Several factors were responsible for the slump in oil prices. Economic turmoil and recession led to a dramatic contraction in Asian oil consumption. Demand was further depressed by the unusually warm (El Niño) winter of 1997-98. Overall, global oil consumption increased $1 / 2$ percent in 1998 , in stark contrast to 1997's strong growth of $2 \frac{1}{2} 2$ percent. On the supply side, OPEC, after making an untimely decision to raise quotas in late 1997, increased production just as demand was weakening. Moreover,

\section{Oil prices, 1985-March 1999}

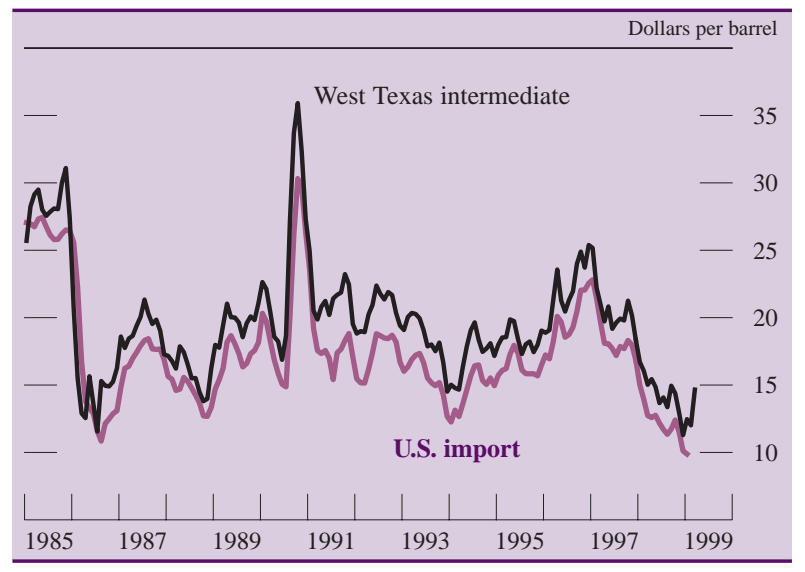

Note. The data are monthly.

SouRCE. Petroleum Intelligence Weekly, various issues, and U.S. Department of Commerce, Bureau of Economic Analysis. 
1998 saw the return of substantial exports from Iraq as production there increased nearly 1 million barrels per day from 1997 levels. Over most of the year, OPEC and non-OPEC producers attempted to curtail production in an effort to support prices. Major producers, led by Saudi Arabia, Mexico, and Venezuela, agreed to restrict production in March and again in June, but a combination of weak demand, increasing production by Iraq, and a high level of stocks prevented any substantial firming of prices.

Prices of world non-oil primary commodities fell 13 percent in over the four quarters of 1998 (chart 6). The financial crises in Asia, Russia, and Latin America, and resulting economic slowdowns, sharply reduced demand for primary commodities. In addition, the appreciation of the dollar-which raises the local-currency price of goods traded in dollarsfurther reduced foreign demand and encouraged foreign producers to turn their attention from their sagging domestic markets to export markets. ${ }^{2}$ The world supply of many commodities also was robust because producers had boosted production levels in response to the high prices recorded in the mid-1990s. These supply responses were widespread across commodities and were especially large for agricultural products, such as grains, oilseeds, and coffee.

\section{Prices of U.S. Non-Oil Imports and Exports}

Overall, U.S. non-oil import prices declined 33/4 percent in 1998 (table 3). When prices of computers

2. This pattern also applied to steel.

6. Prices of world non-oil primary commodities, 1985-March 1999

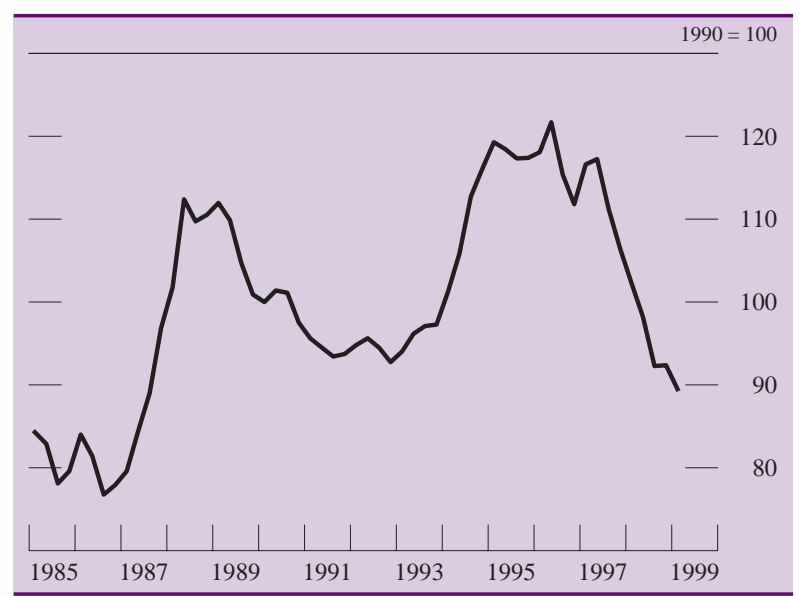

Note. The data are quarterly.

Source. International Monetary Fund, International Financial Statistics, index of non-oil commodity prices.
3. Change in prices of U.S. goods imports and exports Percent, fourth quarter to fourth quarter

\begin{tabular}{|c|c|c|c|}
\hline Item & 1996 & 1997 & 1998 \\
\hline Total goods imports .. & -2.9 & -4.3 & -6.1 \\
\hline Oil .... & 38.8 & -20.2 & -35.9 \\
\hline Non-oil $\ldots \ldots \ldots \ldots \ldots \ldots \ldots$ & -6.1 & -2.5 & -3.7 \\
\hline $\begin{array}{c}\text { Computers, peripherals, and } \\
\text { parts } \ldots \ldots \ldots \ldots \ldots \ldots \ldots \ldots\end{array}$ & -18.9 & -13.4 & -17.8 \\
\hline Semiconductors $\ldots \ldots \ldots \ldots$ & -53.3 & -14.9 & -8.2 \\
\hline Other goods .... & -.6 & -.7 & -2.1 \\
\hline $\begin{array}{l}\text { MEMO } \\
\text { Industrial supplies . }\end{array}$ & -2.8 & -.1 & -6.7 \\
\hline Total goods exports . & -4.7 & -2.2 & -3.5 \\
\hline Agricultural products . & -2.6 & -3.2 & -9.8 \\
\hline Nonagricultural goods ......... & -5.0 & -2.1 & -2.9 \\
\hline $\begin{array}{l}\text { Computers, peripherals, and } \\
\text { parts }\end{array}$ & -26.6 & & -120 \\
\hline 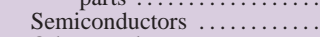 & -33.1 & -13.3 & -5.4 \\
\hline Other goods .......... & -0.1 & .5 & -1.9 \\
\hline $\begin{array}{l}\text { MEMO } \\
\text { Industrial supplies . }\end{array}$ & -2.8 & -0.5 & -7.3 \\
\hline
\end{tabular}

SourCE. U.S. Department of Commerce, Bureau of Economic Analysis, national income and product accounts; chain-weighted indexes; and Federal Reserve Board.

and semiconductors are excluded, the import price declines were smaller, 2 percent, but still showed a larger drop than in previous years. ${ }^{3}$ Much of the weakness in prices of these imported goods in 1998 was attributable to industrial supplies whose prices dropped sharply in 1998 compared with an almost zero change in price in the previous year. In contrast, prices of other categories of imported goods, such as automotive products, consumer goods, and other capital equipment (excluding computers and semiconductors) declined at rates of $1 \frac{1}{2}$ percent or less in 1998, little different from rates recorded in 1997.

The rate of decline in the non-oil import price index slowed noticeably at the end of 1998. For many major categories of trade, with the notable exception of industrial supplies, prices of imports swung to small increases in the fourth quarter from declines in previous quarters.

Prices of U.S. agricultural exports fell 10 percent in 1998 largely as a result of developments in world grain and oilseed markets. As described above, foreign domestic demand sagged in 1998, and the appreciation of the U.S. dollar had the effect of raising local-currency prices. In addition, world supplies of agricultural products were robust because of a lagged response to the very high agricultural prices of the

3. The indexes of prices of computers and semiconductors generally measure units of computing power. Except for prices of semiconductors, which rose somewhat in the fourth quarter, these price indexes continued to drop at notable rates in 1998. 
mid-1990s. While much of production gains worldwide reflected a return to trend-level yields, part of the rebound can be attributed to an increase in the amount of land devoted to these crops. These worldwide production increases brought prices back to near their average levels in the early 1990s.

Prices of nonagricultural exports declined 3 percent in 1998. When computers and semiconductors are excluded, the decrease in the index for export prices was smaller but still showed a drop in prices compared with earlier years. In 1998, a sharp decline in prices of exported industrial supplies contrasted with smaller price changes for other exported goods. Price increases of 1 percent or less were recorded for exported aircraft and automotive products. Price declines of $1 / 2$ percent or less were recorded for exported consumer goods and machinery (other than computers and semiconductors).

\section{International Price Competitiveness of U.S. Goods}

The major factor contributing to gains and losses in U.S. international price competitiveness has been movements in exchange rates. From the fourth quarter of 1996 through third quarter of 1998, the dollar appreciated sharply in real terms -17 percent-on a broad weighted-average basis. In the fourth quarter of 1998, the real dollar reversed some of that movement before turning up again in the first quarter of 1999. Over the same period, the price competitiveness of U.S. goods weakened steadily. Prices of U.S. imported goods measured in dollars relative to U.S. domestic prices declined in 1998 for the third consecutive year (chart 7). Similarly, U.S. goods lost competitiveness in foreign markets. Overall, the sagging price competitiveness of U.S. goods tended to hold down the expansion of exports and support the expansion of imports.

\section{DEVELOPMENTS IN U.S. TRADE IN GOODS AND SERVICES}

In 1998 the U.S. trade deficit in goods and services was substantially larger than in 1997 (table 4). The steep decline in the external balance reflected the effects of anemic economic growth abroad on average, robust economic growth in the United States, and declining price competitiveness of U.S. goods as the dollar appreciated.
7. Price competitiveness of U.S. goods, 1992-March 1999

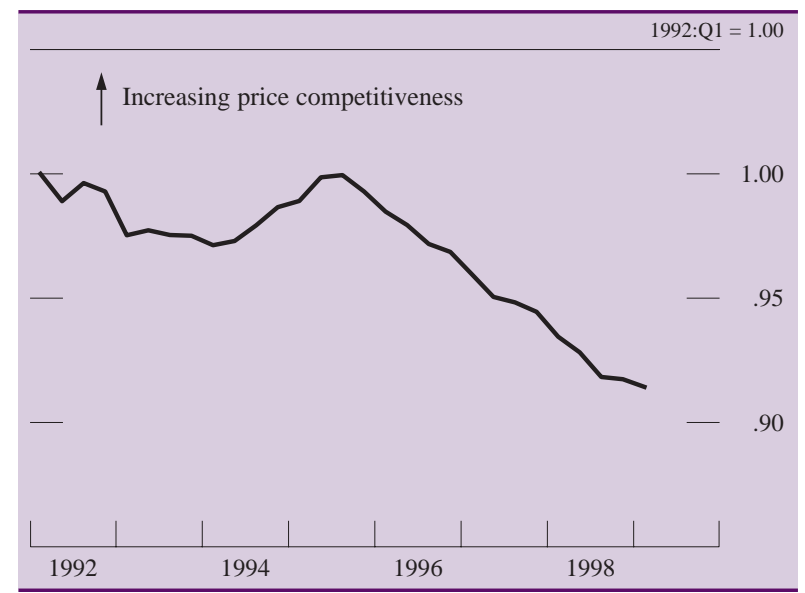

Note. The index is the ratio of the price of U.S. non-oil imports excluding computers and semiconductors to the U.S. GDP deflator. The data are quarterly.

Source. U.S. Department of Commerce, Bureau of Economic Analysis; and Federal Reserve Board.

\section{Exports}

The value of exports of goods and services declined $\$ 6$ billion in 1998 (table 4). Receipts for services rose marginally as increases in receipts from "other private services" (mostly business, professional, technical, and financial services) were nearly offset by declines in receipts from foreign travel to the United States, reduced sales of military equipment, and a drop in freight and port expenditures by foreigners. In contrast, exports of goods fell 1 percent, the first decrease recorded since 1985. Sharp declines in goods exports to emerging markets in Asia and Japan were only partly offset by increased shipments to Western Europe, Canada, and Mexico (table 5).

The value of exports to developing countries in Asia dropped 18 percent, with the sharpest declines recorded in the first quarter. More than three-fourths of U.S. exports to that region are capital goods and industrial supplies, sectors affected severely by the financial crises. Sharp declines were recorded in metals, chemicals, lumber and building materials, power generating equipments, industrial machinery, telecommunications equipment, semiconductors, automotive products, and consumer goods. Deliveries of civilian aircraft to these countries picked up strongly in the second half of the year as financing arrangements were completed for previously ordered planes.

U.S. exports to Japan declined 12 percent in 1998, with decreases in almost all major categories of trade. Particularly large declines were recorded in the value of exported building materials, other industrial supplies, machinery (especially computer accessories, peripherals and parts), automotive vehicles, and agri- 
4. U.S. international trade in goods and services, 1996-98

Billions of dollars except as noted

\begin{tabular}{|c|c|c|c|c|c|}
\hline Item & 1996 & 1997 & 1998 & $\begin{array}{l}\text { Dollar change, } \\
1997 \text { to } 1998\end{array}$ & $\begin{array}{l}\text { Percentage change, } \\
1997 \text { to } 1998\end{array}$ \\
\hline Balance on goods and services & -109 & -110 & -169 & -59 & $\ldots$ \\
\hline Exports of goods and services & 851 & 938 & 931 & -6 & -.7 \\
\hline Services ................... & 239 & 258 & 260 & 2 & .8 \\
\hline Goods $\ldots \ldots \ldots \ldots \ldots$ & 612 & 679 & 671 & -8 & -1.2 \\
\hline Agricultural products & 61 & 58 & 53 & -5 & -9.1 \\
\hline Nonagricultural goods & 550 & 621 & 618 & -3 & -.5 \\
\hline Capital goods ....... & 253 & 295 & 300 & 5 & 1.6 \\
\hline Aircraft and parts ….............. & 31 & 41 & 54 & 12 & 29.5 \\
\hline Computers, peripherals, and parts & 44 & 49 & 45 & -4 & -8.3 \\
\hline Semiconductors .................. & 36 & 39 & 38 & -1 & -2.8 \\
\hline Other machinery and equipment & 143 & 166 & 163 & -3 & -1.7 \\
\hline Industrial supplies ... & 138 & 148 & 138 & -10 & -6.4 \\
\hline Automotive products & 65 & 74 & 73 & -1 & -1.8 \\
\hline Consumer goods ..... & 70 & 77 & 80 & 2 & 2.7 \\
\hline Food and other goods & 24 & 26 & 28 & 2 & 6.2 \\
\hline Imports of goods and services & 959 & 1,048 & 1,101 & 53 & 5.0 \\
\hline Services ................... & 156 & 171 & 182 & 11 & 6.5 \\
\hline Goods .. & 803 & 877 & 919 & 42 & 4.8 \\
\hline Oil ........... & 73 & 72 & 51 & -21 & -28.7 \\
\hline Non-oil goods & 731 & 806 & 868 & 62 & 7.7 \\
\hline Capital goods ....... & 229 & 254 & 270 & 16 & 6.4 \\
\hline Aircraft and parts $\ldots \ldots \ldots \ldots \ldots$ & 13 & 17 & 22 & 5 & 30.1 \\
\hline Computers, peripherals, and parts & 62 & 70 & 73 & 2 & 3.3 \\
\hline Semiconductors ................. & 37 & 37 & 33 & -4 & -9.5 \\
\hline Other machinery and equipment & 118 & 131 & 143 & 12 & 9.4 \\
\hline Industrial supplies ... & 137 & 146 & 152 & 7 & 4.5 \\
\hline Automotive products & 129 & 141 & 151 & 10 & 7.0 \\
\hline Consumer goods ..... & 171 & 193 & 216 & 23 & 11.8 \\
\hline Food and other goods & 65 & 72 & 79 & 7 & 9.7 \\
\hline
\end{tabular}

SOURCE. U.S. Department of Commerce, Bureau of Economic Analysis, U.S. international transactions accounts.

cultural products. On the other hand, exports of aircraft to Japan rose strongly.

In contrast, exports to Western Europe rose in 1998 as economic activity in Europe expanded moderately. Export growth was boosted by strong rates of expansion of aircraft, machinery (other than computers and semiconductors), automotive vehicles, and consumer goods. Similarly, exports to Canada rose in 1998

5. U.S. exports of goods to its major trading partners, 1996-98

Billions of dollars

\begin{tabular}{|c|c|c|c|c|}
\hline Importing region & 1996 & 1997 & 1998 & $\begin{array}{l}\text { Change, } \\
1997 \text { to } 1998\end{array}$ \\
\hline Total goods exports & 612 & 679 & 671 & -8 \\
\hline $\begin{array}{l}\text { Asia } \ldots \ldots \ldots \ldots \\
\text { Japan } \ldots \ldots \ldots \ldots \\
\text { Other Asia }{ }^{1} \ldots\end{array}$ & $\begin{array}{r}176 \\
66 \\
110\end{array}$ & $\begin{array}{r}183 \\
65 \\
118\end{array}$ & $\begin{array}{r}154 \\
57 \\
97\end{array}$ & $\begin{array}{r}-29 \\
-8 \\
-21\end{array}$ \\
\hline $\begin{array}{r}\text { Latin America ..... } \\
\text { Mexico ........ } \\
\text { Other countries } \\
\text { Brazil ........ }\end{array}$ & $\begin{array}{r}109 \\
57 \\
52 \\
12\end{array}$ & $\begin{array}{r}134 \\
71 \\
63 \\
16\end{array}$ & $\begin{array}{r}142 \\
79 \\
64 \\
15\end{array}$ & $\begin{array}{r}8 \\
8 \\
0 \\
-1\end{array}$ \\
\hline $\begin{array}{l}\text { Canada ......... } \\
\text { Western Europe } \\
\text { All other }{ }^{2} \ldots \ldots\end{array}$ & $\begin{array}{r}135 \\
138 \\
54\end{array}$ & $\begin{array}{r}152 \\
153 \\
57\end{array}$ & $\begin{array}{r}157 \\
160 \\
59\end{array}$ & $\begin{array}{l}5 \\
7 \\
2\end{array}$ \\
\hline
\end{tabular}

1. Includes China, Hong Kong, Korea, Singapore, Taiwan, Indonesia, Philippines, Malaysia, and Thailand.

2. Includes Australia, New Zealand, Middle East, Eastern Europe, and Africa.

SourCE. U.S. Department of Commerce, Bureau of Economic Analysis, U.S. international transactions accounts. largely in response to the strength of Canadian domestic demand.

U.S. exports to Mexico expanded more than 10 percent in 1998, with increases spread over all major trade categories, despite a drag on domestic demand from the effects of lower oil prices and financial crises around the world. About 35 percent of U.S. exports to Mexico was machinery, 25 percent was industrial supplies, and automotive products and consumer goods each amounted to about 15 percent. Exports to Mexico account for 12 percent of all U.S. exports and just over half of U.S. exports to Latin America.

Exports to other countries in Latin America were about the same in 1998 as in 1997. Shipments to Brazil declined, as did exports to Chile and Colombia. U.S. shipments to Brazil amount to 2 percent of U.S. exports and are primarily capital goods and industrial supplies.

Although the quantity of exports of goods and services rose slightly for the year, ${ }^{4}$ export growth was quite different between the first and second halves (table 6). In the first half of 1998, exports declined

4. The value of exports of goods and services declined 1 percent in 1998 (Q4/Q4), prices declined 2 percent, and quantity rose 1 percent. This small increase in real exports in 1998 contrasts with growth of 10 percent in each of the previous two years. 
6. Change in the quantity of U.S. exports, 1997-98

Percent, annual rate

\begin{tabular}{|c|c|c|c|}
\hline \multirow{2}{*}{ Item } & \multicolumn{3}{|c|}{ Half years } \\
\hline & 1997:H2 & 1998:H1 & 1998:H2 \\
\hline Exports of goods and services . & 7 & -5 & 8 \\
\hline $\begin{array}{l}\text { Services } \\
\text { Goods }^{1} \text {. }\end{array}$ & $\begin{array}{r}1 \\
10\end{array}$ & $\begin{array}{r}0 \\
-7\end{array}$ & $\begin{array}{l}-1 \\
12\end{array}$ \\
\hline $\begin{array}{l}\text { Agricultural products } \ldots \ldots \\
\text { Industrial supplies ......... }\end{array}$ & $\begin{array}{r}20 \\
3\end{array}$ & $\begin{array}{r}-17 \\
-6\end{array}$ & $\begin{array}{r}18 \\
1\end{array}$ \\
\hline $\begin{array}{l}\text { Capital equipment } \ldots \ldots \ldots \ldots \ldots \ldots \\
\text { Aircraft and parts } \ldots \ldots \ldots \ldots \ldots \ldots \\
\text { Computers, peripherals, and parts } \\
\text { Semiconductors } \ldots \ldots \ldots \ldots \ldots \ldots \ldots \\
\text { Other machinery and equipment }\end{array}$ & $\begin{array}{l}15 \\
22 \\
13 \\
14 \\
14\end{array}$ & $\begin{array}{r}-9 \\
4 \\
-4 \\
-11 \\
-13\end{array}$ & $\begin{array}{r}22 \\
122 \\
18 \\
35 \\
-2\end{array}$ \\
\hline $\begin{array}{l}\text { Automotive vehicles and parts } \\
\text { Consumer goods } \ldots \ldots \ldots \ldots \ldots . . .\end{array}$ & $\begin{array}{l}9 \\
1\end{array}$ & $\begin{array}{r}-11 \\
4\end{array}$ & $\begin{array}{r}4 \\
-1\end{array}$ \\
\hline
\end{tabular}

Note. Quantities are measured in chained (1992) dollars.

1. Selected categories are shown below.

SouRCE. U.S. Department of Commerce, national income and product accounts.

5 percent at an annual rate, with much of the decline in agricultural products, machinery, automotive products, and industrial supplies. In the second half of the year, exports rebounded. Exports were boosted by a surge in deliveries of aircraft to developing countries in Asia and by a jump in exports of automotive parts to U.S. producers in Canada that reflected the strong demand for completed vehicles in the United States. Exports of computers and semiconductors both picked up in the second half of the year after declining in the first half. ${ }^{5}$ Most important was the decline in other machinery, which slowed significantly in the second half of the year as the slide in economic activity abroad (particularly Asia) began to abate.

\section{Imports}

The value of imports of goods and services rose 5 percent over the four quarters of 1998, with increases recorded in all major trade categories except oil and semiconductors (table 4). Prices of imports declined 5 percent on average. Adjusted for changes in prices, imports of goods and services expanded 10 percent during 1998 in response to robust growth of U.S. domestic demand.

The quantity of imported oil grew 6 percent in 1998 (table 7), rising to 11.2 million barrels per day. Strong U.S. economic activity and low real oil prices

5. Nearly two-thirds of U.S. exports of semiconductors (generally high-end products, and often for further assembly) go to developing countries in Asia and Japan, as does nearly one-third of U.S. exports of computers, peripherals, and parts. Canada and Western Europe take more than one-fourth of U.S. exports of semiconductors and more than half of U.S. exports of computers.
7. Change in the quantity of imports, 1996-98

Percent, annual rate

\begin{tabular}{|c|c|c|c|}
\hline Item & 1996 & 1997 & 1998 \\
\hline Imports of goods and services & 12 & 14 & 10 \\
\hline Services & 5 & 12 & 2 \\
\hline Goods . & 13 & 14 & 11 \\
\hline & 8 & 4 & 6 \\
\hline Non-oil ${ }^{1}$ & 14 & 15 & 11 \\
\hline Industrial supplies & 12 & 8 & 8 \\
\hline Capital goods .................. & 19 & 24 & 11 \\
\hline Automotive vehicles and parts & 9 & 9 & 16 \\
\hline Consumer goods .............. & 14 & 15 & 9 \\
\hline Foods ........... & 13 & 9 & 5 \\
\hline
\end{tabular}

NoTE. Quantities are measured in chained (1992) dollars.

1. Selected categories are shown below.

SouRCE. U.S. Department of Commerce, national income and product accounts.

kept consumption up while domestic production declined. Increased production in the Gulf of Mexico was insufficient to offset declines elsewhere. Smallscale production, from what are known as stripper wells, has been particularly hard hit by low oil prices. Despite the increased quantity of imports, the value of imported oil declined 29 percent in 1998, to $\$ 51$ billion.

Real non-oil imports grew 11 percent in 1998 (table 7). An expansion in a broad range of goods was fueled by robust growth of U.S. domestic demand and was supported by declines in non-oil import prices. Reflecting the strength of spending by households and businesses in the United States, real imports of consumer goods and capital equipment (other than semiconductors) advanced steadily throughout the year, and imports of non-oil industrial supplies rose sharply through the third quarter before leveling off in the fourth quarter. The growth of automotive imports in 1998 reflected the buoyant picture for automotive sales in the United States. Although the strike against GM restrained imports of vehicles and parts from Canada and Mexico in the third quarter and boosted imports somewhat in the fourth quarter, an important part of the surge in automotive imports in 1998:Q4 reflected record vehicle sales in the United States in the closing months of the year.

The value of imported semiconductors, which declined during most of the year, was heavily influenced by the rapid price declines characteristic of the industry in recent years. U.S. domestic demand for semiconductors remained strong in 1998. Eighty-five percent of U.S. imports of semiconductors are from developing countries in Asia and Japan and generally are finished low-end products previously shipped to those countries from the United States for testing.

Payments to foreigners for services rose moderately in 1998, with increases in most service catego- 
ries but especially in travel (U.S. residents traveling abroad) and in other private services.

\section{DEVELOPMENTS IN THE NONTRADE CURRENT ACCOUNT}

The two major components of the current account other than trade in goods and services are net investment income and net unilateral transfers (table 8).

\section{Investment Income}

Net investment income is the difference between the amount that U.S. residents earn on their direct and portfolio investment abroad (receipts) and the amount that foreigners earn on their direct and portfolio investment in the United States (payments). ${ }^{6}$ Until 1997, net investment income had helped offset persistent trade deficits. But as the U.S. net external debt has continued to rise rapidly in recent years, net investment income has become increasingly negative, moving from a \$14 billion surplus in 1996 to a \$22 billion deficit in 1998. Net portfolio income became more negative during 1998 as the portfolio liability position of the United States grew larger. In addition, net income from direct investment was reduced last year.

\section{Direct Investment Income}

Net direct investment income-the difference between direct investment receipts from U.S. direct investment abroad and U.S. payments on foreign direct investment in the United States-fell $\$ 9$ billion in 1998 , to $\$ 55$ billion.

Receipts of income on U.S. direct investment abroad fell to $\$ 100$ billion, declining about $\$ 9$ billion because of slower economic growth abroad, lower petroleum prices, and in some cases, the appreciation of the dollar. Despite solid growth in income receipts from Western Europe, the overall performance showed weakness in all other geographic areas. Profits were down from 25 percent to 50 percent in areas directly affected by the Asian crisis: Japan, other Asian countries, and Australia; notable exceptions to

6. An investment is considered direct if a single owner acquires 10 percent or more of the voting equity in a company. All other U.S. claims on foreigners or foreign claims on the United States are included in the other category-portfolio investment.
8. U.S. direct investment abroad: Position and receipts, 1980-98

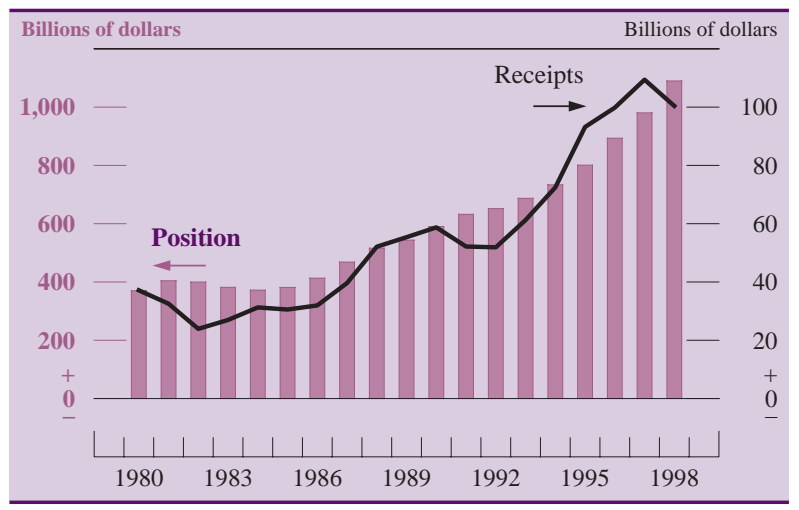

Note. The position data are averages using the current-cost measures as of year-end for the current and previous years. The year-end data for 1998 were constructed by adding the recorded direct investment capital flows and current cost adjustment during 1998 to the recorded year-end position for 1997.

SourCE. U.S. Department of Commerce, Bureau of Economic Analysis; and Federal Reserve Board.

this downward trend were Korea and Thailand where profits turned up. Operations in Canada and Latin America showed smaller but still significant profit declines of about 20 percent. On an industry basis, income from operations in petroleum, manufacturing, and commercial banking (depository institutions) were particularly hard hit; profits in the categories of "wholesale trade" and "finance, insurance and real estate" were above their 1997 levels.

Income receipts from direct investment abroad fell despite robust growth of U.S. direct investment assets abroad in both 1997 and 1998 (chart 8). On a current cost basis, the rate of return on direct investment fell

9. Foreign direct investment in the United States: Position and payments, 1980-98

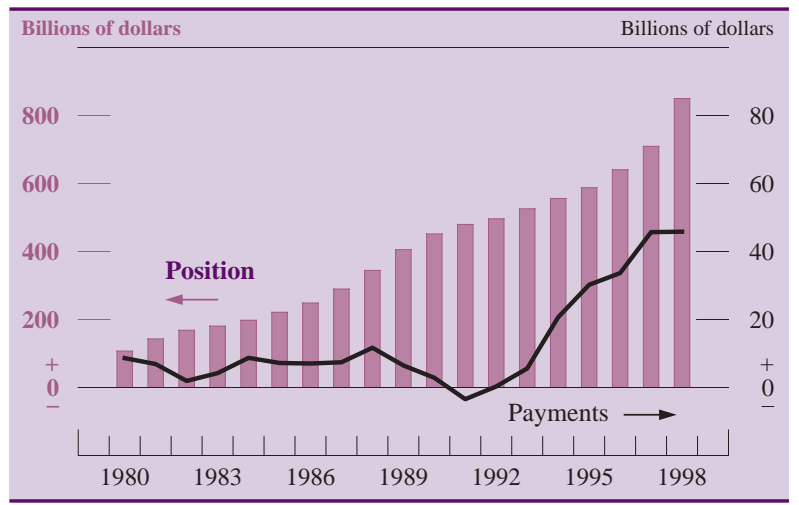

Note. The position data are averages using the current-cost measures as of year-end for the current and previous years. The year-end data for 1998 were constructed by adding the recorded direct investment capital flows and currentcost adjustment during 1998 to the recorded year-end position for 1997.

SourCE. U.S. Department of Commerce, Bureau of Economic Analysis; and Federal Reserve Board. 
8. U.S. net investment income and unilateral transfers, 1994-98

Billions of dollars

\begin{tabular}{|c|c|c|c|c|c|c|}
\hline Item & 1994 & 1995 & 1996 & 1997 & 1998 & $\begin{array}{l}\text { Change, } \\
1997 \text { to } 1998\end{array}$ \\
\hline Investment income, net & 16 & 19 & 14 & -5 & -22 & -17 \\
\hline Direct investment income, net & 52 & 63 & 66 & 64 & 55 & -9 \\
\hline Receipts ................. & 72 & 93 & 100 & $\begin{array}{r}04 \\
109\end{array}$ & 100 & -9 \\
\hline Payments & 21 & 30 & 34 & 46 & 46 & 0 \\
\hline Portfolio investment income, net & -35 & -44 & -52 & -69 & -77 & -8 \\
\hline Receipts .................. & 85 & 111 & 113 & 132 & 142 & 10 \\
\hline Payments . & 121 & 154 & 165 & 201 & 219 & 18 \\
\hline Unilateral transfers & -39 & -35 & -41 & -40 & -42 & -2 \\
\hline
\end{tabular}

SourCE. U.S. Department of Commerce, Bureau of Economic Analysis, U.S. international transactions accounts.

2 percentage points, from 11.2 percent in 1997 to 9.2 percent in $1998 .^{7}$

Income payments on foreign direct investment in the United States, at $\$ 46$ billion for 1998, were virtually the same as the 1997 totals, a pattern quite consistent with the overall picture for corporate profits of domestic U.S. firms in 1998. In view of the strong growth of foreign investment in the United States in 1998, the level of income payments in 1998 represents a fall-off in the rate of return of 1 percent (chart 9).

\section{Portfolio Investment Income}

Portfolio investment income consists of dividends and interest paid on a wide range of claims and liabilities. Receipts and payments are estimated by the Bureau of Economic Analysis (BEA) of the Department of Commerce on the basis of its estimates of holdings, dividend-payout ratios, and interest rates. Investment income does not include capital gains associated with changes in securities prices. The balance on portfolio income, which is the difference between what U.S. residents earned on their holdings abroad and what foreign residents earned on their investment in the United States, registered a deficit of $\$ 77$ billion in 1998, a gap $\$ 8$ billion larger than in 1997 (table 8). The balance on portfolio income has been in deficit since 1985, and its size has broadly mirrored the net portfolio investment position (chart 10). While the net position is the primary

7. Valuing direct investment assets on a current cost basis implies adjusting the historical cost of inventories and plant and equipment to reflect movements in current replacement cost indexes. In calculating the rates of return noted in this section, we use in the denominator the current-cost measure of the year-end direct investment position averaged for the current and previous year; this position average is shown in charts 8 and 9. determinate of net income, the level of U.S. and foreign interest rates (rates of return) also play a role. The role for interest rates was particularly evident last year as the decline in U.S. and foreign interest rates reduced the rates of return on portfolio investment and dampened the rise in the deficit (chart 11).

\section{Unilateral Transfers}

Net unilateral transfers include government grant and pension payments as well as net private transfers to foreigners. In 1998, net transfers amounted to $\$ 42$ billion, about the same as in 1997.

\section{CAPITAL FLOWS}

The large U.S. current account deficit last year was entirely financed by net capital inflows from private

10. Net portfolio investment: Position and income, 1980-98

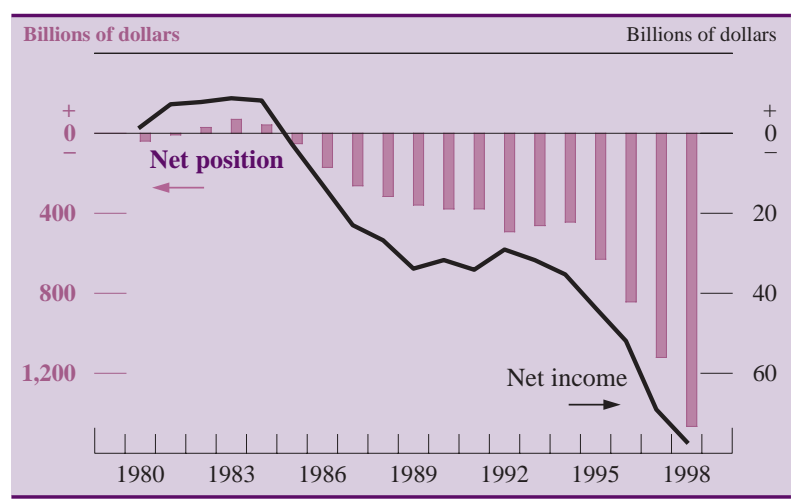

Note. The net position data are averages of the end-of-year net positions for the current and previous years. The year-end position for 1998 was constructed by adding the recorded portfolio investment flows during 1998 to the recorded year-end position for 1997.

SourCE. U.S. Department of Commerce, Bureau of Economic Analysis; and Federal Reserve Board. 
11. Rates of return on U.S. portfolio investment, 1988-98

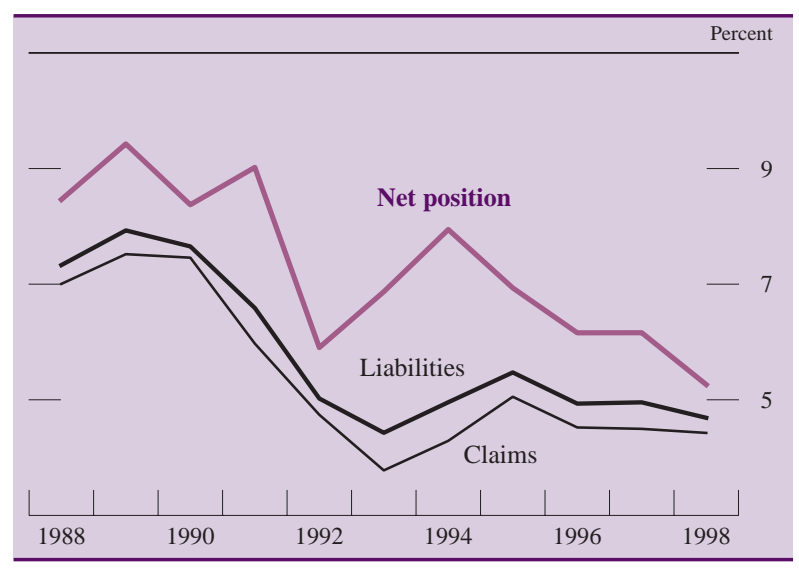

Note. The rates of return are annualized versions of quarterly rates calculated as follows: For claims (or liabilities), the numerator is total receipts (or payments) from the U.S. international transactions accounts, measured on a quarterly basis. The denominator is the average of end-of-quarter claims (or liabilities) for the current and previous quarters. To compute the numerator and denominator of the annualized rate of return, the numerators and denominators from the four quarterly rates of return are averaged.

The rate of return on the net position is calculated as the ratio of net investment income (annual receipts minus payments) to the annualized net position (annualized claims minus annualized liabilities).

SouRCE. U.S. Department of Commerce, Bureau of Economic Analysis, U.S. international transactions accounts and U.S. international investment position; and Federal Reserve Board.

sources (table 9). Official capital flows, which registered modest inflows in 1997, turned to significant outflows last year as the financial turmoil in the third quarter caused many countries to draw down their official reserves.
Foreign official assets in the United States rose $\$ 11$ billion in the first quarter of 1998 but fell \$10 billion in the second quarter. Reductions in Japanese reserves in the United States, which were associated with foreign exchange market intervention, more than account for the second quarter decline. (An increase in official assets in the United States represents a capital inflow and a reduction in reserves represents a capital outflow.) Official outflows accelerated in the third quarter as OPEC and developing countries significantly reduced their reserves in the United States. Official flows to the United States turned positive again in the fourth quarter, but for the year as a whole foreign official assets in the United States fell \$22 billion.

The turmoil in the third quarter also affected the composition of private capital flows. Private foreign net purchases of U.S. corporate and government agency bonds totaled more than $\$ 100$ billion in the first two quarters of 1998, somewhat above the pace of 1997 . These net purchases slowed to $\$ 26$ billion in the third quarter and then rebounded to $\$ 41$ billion in the fourth quarter. Private foreign net purchases of U.S. Treasury securities and U.S. stocks followed a similar, but more pronounced, pattern. Net purchases in the first half of 1998 were followed by sales in the third quarter and a resumption of net purchases in the fourth quarter.

U.S. net purchases of foreign securities also responded to the financial turmoil. Net purchases were

9. Composition of U.S. capital flows, 1994-98

Billions of dollars

\begin{tabular}{|c|c|c|c|c|c|c|c|}
\hline \multirow{2}{*}{ Item } & \multirow{2}{*}{1996} & \multirow{2}{*}{1997} & \multirow{2}{*}{1998} & \multicolumn{4}{|c|}{1998} \\
\hline & & & & Q1 & Q2 & Q3 & Q4 \\
\hline Current account balance ... & -135 & -155 & -233 & -47 & -57 & -66 & -64 \\
\hline $\begin{array}{l}\text { Official capital, net } \ldots \ldots \ldots \ldots \ldots \ldots \ldots \ldots \\
\quad \text { Foreign official assets in the United States } \ldots \ldots \ldots \ldots \ldots \\
\text { U.S. official reserve assets } \ldots \ldots \ldots \ldots \ldots \ldots \ldots \ldots \ldots \\
\text { Other U.S. government assets } \ldots \ldots \ldots \ldots \ldots \ldots \ldots \ldots \\
\end{array}$ & $\begin{array}{r}133 \\
127 \\
7 \\
-1\end{array}$ & $\begin{array}{r}15 \\
16 \\
-1 \\
0\end{array}$ & $\begin{array}{r}-30 \\
-22 \\
-7 \\
-1\end{array}$ & $\begin{array}{l}\mathbf{1 1} \\
11 \\
-0 \\
-0\end{array}$ & $\begin{array}{r}-13 \\
-10 \\
-2 \\
-0\end{array}$ & $\begin{array}{r}-48 \\
-46 \\
-2 \\
0\end{array}$ & $\begin{array}{l}21 \\
23 \\
-2 \\
-0\end{array}$ \\
\hline $\begin{array}{l}\text { Private capital, net } \ldots \ldots \ldots \ldots \ldots \ldots \ldots \ldots \ldots \\
\quad \text { Net inflows reported by U.S. banking offices } \ldots \ldots \ldots \\
\text { Securities transactions, net } \ldots \ldots \ldots \ldots \ldots \ldots \ldots \ldots\end{array}$ & $\begin{array}{r}61 \\
-75 \\
169\end{array}$ & $\begin{array}{r}240 \\
1 \\
256\end{array}$ & $\begin{array}{r}267 \\
12 \\
176\end{array}$ & $\begin{array}{r}39 \\
-47 \\
68\end{array}$ & $\begin{array}{l}68 \\
13 \\
70\end{array}$ & $\begin{array}{l}87 \\
45 \\
36\end{array}$ & $\begin{array}{r}74 \\
1 \\
2\end{array}$ \\
\hline $\begin{array}{l}\text { Private foreign net purchases of U.S. securities . } \\
\text { Treasury securities } \ldots \ldots \ldots \ldots \ldots \ldots \ldots \ldots \ldots \\
\text { Corporate and other bonds } \ldots \ldots \ldots \ldots \ldots \ldots \ldots \\
\text { Corporate stocks } \ldots \ldots \ldots \ldots \ldots \ldots \ldots \ldots \ldots \ldots\end{array}$ & $\begin{array}{r}285 \\
155 \\
119 \\
11\end{array}$ & $\begin{array}{r}344 \\
147 \\
131 \\
66\end{array}$ & $\begin{array}{r}265 \\
48 \\
171 \\
46\end{array}$ & $\begin{array}{l}75 \\
-2 \\
48 \\
29\end{array}$ & $\begin{array}{l}98 \\
27 \\
57 \\
14\end{array}$ & $\begin{array}{l}19 \\
-1 \\
26 \\
-6\end{array}$ & $\begin{array}{r}74 \\
24 \\
41 \\
8\end{array}$ \\
\hline $\begin{array}{l}\text { U.S. net purchases of foreign securities ... } \\
\text { Stocks } \ldots \ldots \ldots \ldots \ldots \ldots \ldots \ldots \ldots \ldots \ldots \\
\text { Bonds } \ldots \ldots \ldots \ldots \ldots \ldots \ldots \ldots \ldots \ldots \ldots \ldots \ldots \ldots \ldots\end{array}$ & $\begin{array}{r}-116 \\
-60 \\
-56\end{array}$ & $\begin{array}{l}-88 \\
-41 \\
-47\end{array}$ & $\begin{array}{l}-89 \\
-76 \\
-13\end{array}$ & $\begin{array}{l}-7 \\
-3 \\
-4\end{array}$ & $\begin{array}{r}-28 \\
-1 \\
-27\end{array}$ & $\begin{array}{r}17 \\
8 \\
9\end{array}$ & $\begin{array}{r}-72 \\
-80 \\
8\end{array}$ \\
\hline $\begin{array}{l}\text { Direct investment, net } \ldots \ldots \ldots \ldots \ldots \ldots \ldots \ldots \\
\quad \text { Foreign direct investment in the United States .... } \\
\text { U.S. direct investment abroad } \ldots \ldots \ldots \ldots \ldots \ldots \ldots \ldots\end{array}$ & $\begin{array}{r}-4 \\
78 \\
-81\end{array}$ & $\begin{array}{r}-28 \\
93 \\
-122\end{array}$ & $\begin{array}{r}64 \\
196 \\
-132\end{array}$ & $\begin{array}{r}-9 \\
26 \\
-35\end{array}$ & $\begin{array}{r}-22 \\
19 \\
-41\end{array}$ & $\begin{array}{r}7 \\
30 \\
-23\end{array}$ & $\begin{array}{r}88 \\
121 \\
-33\end{array}$ \\
\hline Foreign holdings of U.S. currency & 17 & 25 & 17 & 1 & 2 & 7 & 6 \\
\hline Other . & -47 & -13 & -2 & 26 & 4 & -8 & -23 \\
\hline Statistical discrepancy & -60 & -100 & -4 & -3 & 2 & 27 & -31 \\
\hline
\end{tabular}

SoURCE. U.S. Department of Commerce, Bureau of Economic Analysis, U.S. international transactions accounts. 
large in the first half of 1998, totaling $\$ 35$ billion. However, net purchases fell to near zero in July and swung to net sales in August. The pace of net sales accelerated through October but then abruptly turned to net purchases again in November and December. Purchases of foreign securities in the fourth quarter also include the effects of two exceptionally large foreign acquisitions of U.S. companies by the exchange of stock in U.S. firms for stock in the newly established foreign parent firms. As a result, significant U.S. net sales of foreign securities in the third quarter shifted to huge net purchases in the fourth.

Net private capital flows through banks buffered the swings in official flows and private securities transactions. Moderate net capital outflows recorded by banks during the first half of 1998 became significant net inflows in the third quarter when many banks brought funds into the United States to supply domestic customers who found they could not directly access the capital markets in the midst of the turmoil. In the fourth quarter, net bank inflows were almost nil.

The pattern of direct investment capital flows was less affected by the mid-year turmoil. Foreign direct investment in the United States and U.S. direct investment abroad were both very strong throughout 1998 . British Petroleum's acquisition of Amoco on December 31 helped swell direct investment capital inflows in the fourth quarter, bringing the total for the year well above the 1997 record.

Total recorded net capital inflows were $\$ 237$ billion in 1998, $\$ 4$ billion more than the recorded current account deficit. In 1997, recorded capital inflows exceeded the current account deficit by $\$ 100$ billion. This difference, the statistical discrepancy, represents the cumulative errors in both the current and capital account data. Rapid swings in the statistical discrepancy, however, are most likely to reflect errors and omissions in the capital flows data, and net capital inflows probably were overstated in both 1997 and 1998.

\section{PROSPECTS FOR 1999}

The fallout from the financial crises in emerging markets is likely to have further negative consequences for U.S. external balances in 1999. Demand for U.S. exports is likely to be held down by weakness in demand from trading partners in Asia and Latin America and by sluggish demand from other major trading partners. The appreciation of the dollar during the past two years and the associated loss in competitiveness of U.S. goods and services is also likely to have a negative effect on the U.S. trade balance in 1999 . 